\title{
Thermal Energy Analysis of Desalination Double Slope Passive Solar Still
}

\author{
Jandri Fan HT. Saragi*, Tambos August Sianturi, Jhon \\ Sufriadi Purba \\ Department of Mechanical Engineering \\ Universitas HKBP Nommensen Pematangsiantar \\ Pematangsiantar, Indonesia \\ *jandrifan@gmail.com
}

\author{
Wawan Septiawan Damanik \\ Department of Mechanical Engineering \\ Universitas Muhammadiyah Sumatera Utara \\ Medan, Indonesia \\ wawanseptiawan@umsu.ac.id
}

\begin{abstract}
Solar distillation is a method of thermal desalination in which water is evaporated using solar energy and the separated water vapor is condensed again as pure water. This is a good practical alternative in offering a renewable energy source that is used to produce clean water in areas where there is a lack of clean water. This study aims to obtain the results of the amount of thermal energy obtained from a passive solar desalination system with a double slope and the factors that greatly affect the amount of thermal energy in the system. In this study, the method used for data collection was an experiment carried out for eight days. From the research results, the highest thermal energy produced is $9.18 \mathrm{kWh}$ and the lowest is $1.23 \mathrm{kWh}$, and the factors that affect the amount of thermal energy are the heat transfer coefficient and the amount of distilled water produced by the system. By knowing the amount of thermal energy produced by the system, areas that have a lack of clean water can use a passive solar desalination system with a double slope that uses solar energy as its energy source.
\end{abstract}

Keywords—thermal energy, desalination, passive solar still

\section{INTRODUCTION}

Water is the source of life on earth, especially for humans. Humans need water for various other needs, such as washing, cooking, bathing, and others. At present, most areas living in coastal areas and peatland areas have few sources of fresh water while the need for fresh water is increasing. People in areas that have few fresh water sources are forced to use water that is a little cloudy and even very cloudy to meet their water needs.

People who live on peatlands or in areas that have water scarcity really need clean water sources to meet their daily needs. In Indonesia, when the dry season arrives, many areas lack clean water and they are even willing to queue long and spend some money to get clean water [1]. The problem of lack of clean water can be overcome if people have new ways to produce their own clean water. Data obtained from WHO shows that water consumption per human is between 60 and 120 liters per day and will even increase dramatically in the 20th century with consumption reaching 75-100 liters per day [2,3].

Desalination is a process to separate salt content and other dissolved elements from water, brackish and seawater. To carry out the desalination process, thermal energy is needed, because water will evaporate when heat energy is given. Since long time ago, the energy used for the desalination process has come from conventional energy, namely fuel from petroleum. Fuel derived from petroleum will produce toxic gas emissions to the environment and the costs incurred are high for obtaining petroleum, especially if it is located far from cities. For now, there have been many studies using renewable energy, namely the largest energy in our solar system, namely solar energy, which uses up to $57 \%$ [4,5]. Solar energy is the emission of light and heat from the sun which can be used for various technological needs. Solar energy can be used to heat water to a temperature of $60^{\circ} \mathrm{C}[6,7]$.

Thermal energy is the internal energy of the thermodynamic equilibrium which is proportional to the absolute temperature and is transferred as heat in the thermodynamic process. In this study, the source of thermal energy comes from solar energy. Thermal energy is used to evaporate water in a solar powered desalination system. Thermal energy in the system is obtained from solar energy through a radiation process where in the desalination system the lid is made of glass so that in the system there is radiation and convection heat transfer and the thermal energy in the system is not wasted into the environment. Desalination of solar energy has long been used, which is about two thousand years ago and on a large scale in 1874 to meet water needs in the second world war [8]. In the future, solar-powered desalination systems will be widely used and developed throughout the world, especially in desert areas, coastal areas and peatland areas to produce water $[1,9]$.

The amount of thermal energy produced by solar desalination devices has been studied before, including research conducted by Lovedeep Sahota and G.N. Tiwari which gets an annual energy of 1101, $64 \mathrm{kWh}$ in a passive solar still desalination [6], research conducted by Lovedeep Sahota, 
Shyam and G.N. Tiwari showed annual thermal energy production of $1101.64 \mathrm{kWh}$ [10], and research conducted by VK Dwivedi and GN Tiwari with an annual energy yield of $325.50 \mathrm{kWh}$ [11]. The results of research that have been carried out by previous researchers aim to determine the amount of thermal energy used to produce clean water based on the amount of solar intensity received by the system.

\section{METHODS}

In this study, using six thermocouples. Two thermocouples are placed on the top glass surface, two on the bottom glass surface, one in seawater and one for measuring the environmental temperature in the basin placed on the basin wall. Other data taken from this study are data on solar intensity, wind speed and environmental temperature around the desalination tool. Basin in this study using Aluminum Composite Panel (ACP) with a thickness of $3 \mathrm{~mm}$. This ACP is coated with styrofoam and aluminum foil to prevent heat transfer by conduction and convection to free air. The length of the basin used is $2 \mathrm{~m}$ with a width of $1 \mathrm{~m}$ and a height of the bottom of the basin is $150 \mathrm{~mm}$ and a height of the top of the basin is 409 so that it forms an angle of $15^{\circ}$. The thickness of the glass used is $3 \mathrm{~mm}$ with a glass size of $1000 \times 1000 \mathrm{~mm}$ of clear glass type. For size, dimensions and symbols used will be shown in table 1 below:

TABLE I. SIZE, DIMENSIONS AND SYMBOLS

\begin{tabular}{|l|l|l|l|}
\hline \multicolumn{1}{|c|}{ Symbol } & \multicolumn{1}{c|}{ Value } & \multicolumn{1}{c|}{ Symbol } & \multicolumn{1}{c|}{ Value } \\
\hline $\mathrm{A}_{\mathrm{b}}$ & $1,932 \mathrm{m \times 1 \textrm {m }}$ & $\alpha_{\mathrm{g}}$ & 0,05 \\
\hline $\mathrm{K}_{\mathrm{g}}$ & $0,78\left(\mathrm{~W} / \mathrm{m}^{\circ} \mathrm{C}\right)$ & $\alpha_{\mathrm{b}}$ & 0,8 \\
\hline $\mathrm{L}_{\mathrm{g}}$ & $0,003 \mathrm{~m}$ & $\alpha_{\mathrm{W}}$ & 0,6 \\
\hline $\mathrm{K}_{\mathrm{i}}$ & $0,039\left(\mathrm{~W} / \mathrm{m}^{\circ} \mathrm{C}\right)$ & $\epsilon_{\mathrm{w}}$ & 0,95 \\
\hline $\mathrm{L}_{\mathrm{i}}$ & $0,02 \mathrm{~m}$ & $\epsilon_{\mathrm{g}}$ & 0,95 \\
\hline$\theta$ & $15^{\circ}$ & $\sigma$ & $5,67 \times 10^{-8}\left(\mathrm{~W} / \mathrm{m}^{2} \mathrm{~K}^{4}\right)$ \\
\hline $\mathrm{x}$ & 0,2595 & $\mathrm{~A}_{\mathrm{gE}}$ & $1 \mathrm{m \times 1} \mathrm{m}$ \\
\hline $\mathrm{M}_{\mathrm{w}}$ & $38,640 \mathrm{Kg}$ & $\mathrm{A}_{\mathrm{gW}}$ & $1 \mathrm{m \times 1m}$ \\
\hline
\end{tabular}

In this study, the basin is placed to the east and west with the assumption that it gets full sun instead of facing north and south, this is done because the basin consists of two glass parts. On the eastern glass, a thermocouple is placed on the top of the glass and another at the bottom to measure the temperature of the glass as well as in the west. A thermocouple is placed on the bottom of the water to measure the temperature of the water during the desalination process and another is placed to measure the temperature in the basin. A thermocouple is placed near the basin to measure the ambient temperature along with sensors of solar radiation and wind velocity that are output directly in MS Excel format.

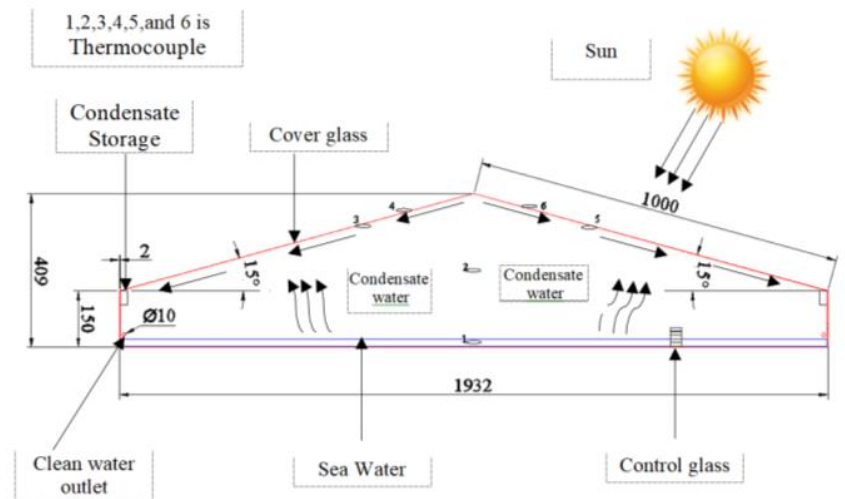

Fig. 1. Design double slope solar still.

In this study, the basin functions as an evaporator where sea water will be given solar heat to evaporate. The time required in this study is six hours starting at 08.00 am and ending at $06.00 \mathrm{pm}$. The first step in this research is to enter the water into a water storage tank to flow into the basin. The water in the basin is filled to the limit of the control glass which is 20 $\mathrm{mm}$. Data recording is done every hour at the same time to control the water level in the basin. If the water level in the basin decreases it is necessary to open the tap on the holding tank. The condensate water will come out through the flow that has been created on the edge of the cover glass through the hose into the clean water reservoir.

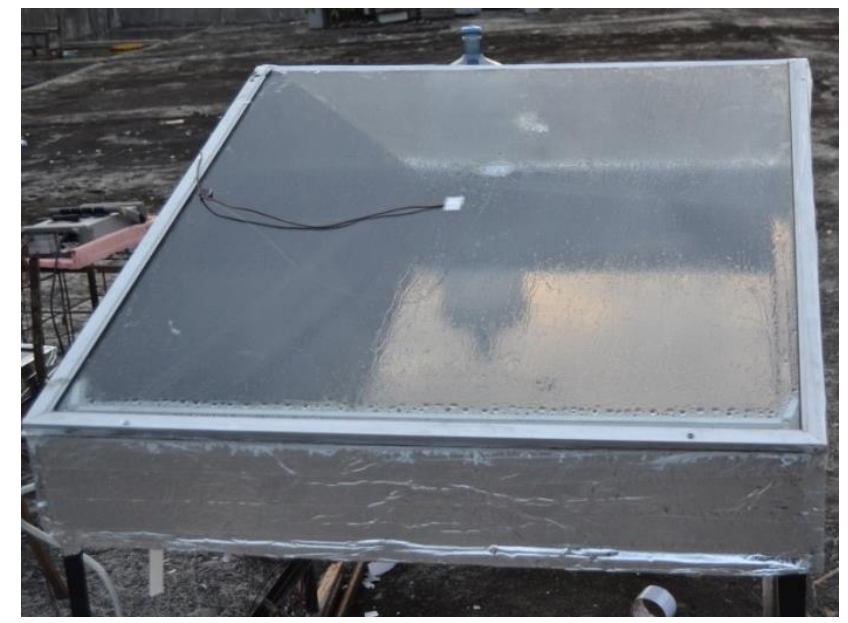

Fig. 2. Double slope solar still.

\section{A. Heat Transfer Coefficient}

The first thing to do in obtaining a thermal energy analysis is to calculate the heat transfer coefficient that occurs, namely radiation heat transfer, convection and evaporation. Radiant heat transfer coefficient hrwg can be calculated using the formula [12,13]:

$$
\left.h_{r w g}=\varepsilon_{e f f} \sigma \mid\left(T_{w}+273\right)^{2}+\left(T_{g i}+273\right)^{2}\right]\left(T_{w}+T_{g i}+546\right)
$$


where $\sigma$ is the number of the Stefan - Boltzman coefficient, $\varepsilon_{\text {eff }}$ is Effective emissivity, $T_{w}$ is Basic fluid temperature and $T_{g i}$ is Inner glass temperature.

For the convection heat transfer coefficient $h_{c w g}$ to occur between the glass and the water surface it can be calculated as follows [12,13]:

$$
h_{c w g}=0.884\left[\left(T_{w}-T_{g i}\right)+\frac{\left(P_{w}-P_{g i}\right) \cdot\left(T_{w}+273\right)}{2.689 \times 10^{5}-P_{w}}\right]^{1 / 3}
$$

Where $\mathrm{P}_{\mathrm{w}}$ is Partial pressure of water and $\mathrm{P}_{\mathrm{gi}}$ is Glass partial pressure,

$$
\begin{aligned}
& P_{w}=\exp \left[25.317-\left(\frac{5144}{273+T_{w}}\right)\right] \\
& P_{g i}=\exp \left[25.317-\left(\frac{5144}{273+T_{g i}}\right)\right]
\end{aligned}
$$

Meanwhile, the evaporation coefficient that occurs can be calculated using the following formula $[12,13]$ :

$$
h_{e w g}=0.016273 h_{c w g}\left(\frac{P_{w}-P_{g i}}{T_{w}-T_{g i}}\right)
$$

\section{B. Desalination Results}

The results for one hour of desalination can be calculated as follows $[12,14,15]$ :

$$
\dot{M}_{e w}=\frac{h_{e w g}\left(T_{w}-T_{g i}\right) 3600}{L}
$$

where, the latent heat of vaporization $\mathrm{L}$ can be expressed as $[4,14]$ :

$$
\begin{gathered}
L=3.1615 \times 10^{6}+\left[1-\left(7.6166 \times 10^{-4} T_{v}\right)\right]_{f o r T}>70^{\circ} C \\
L=2.4935 \times 10^{6}+\left[1-\left(\begin{array}{l}
9.4779 \times 10^{-4}\left(T_{v}\right)+ \\
1.3132 \times 10^{-7}\left(T_{v}^{2}\right)- \\
\left.4.7974 \times 10^{-9}\left(\begin{array}{c}
T_{v}^{3} \\
)
\end{array}\right)\right]_{\text {for } T<70 \cdot C}
\end{array}\right.\right.
\end{gathered}
$$

Where $T_{v}$ is vapor Temperature

\section{Energy analysis}

Each hour of system energy used to obtain distilled water is given as follows $[10,12,16]$ :

$$
E_{\text {Hourly, En }}=\left\lfloor h_{e w g E}\left(T_{w}-T_{g i E}\right)+h_{e w g W}\left(T_{w}-T_{g i W}\right)\right] A_{b}
$$

Where $A_{b}$ is basin area

\section{RESULTS}

The thermal energy in the desalination system comes from solar energy to evaporate water, so that the greater the thermal energy produced, the more water vapor is produced.

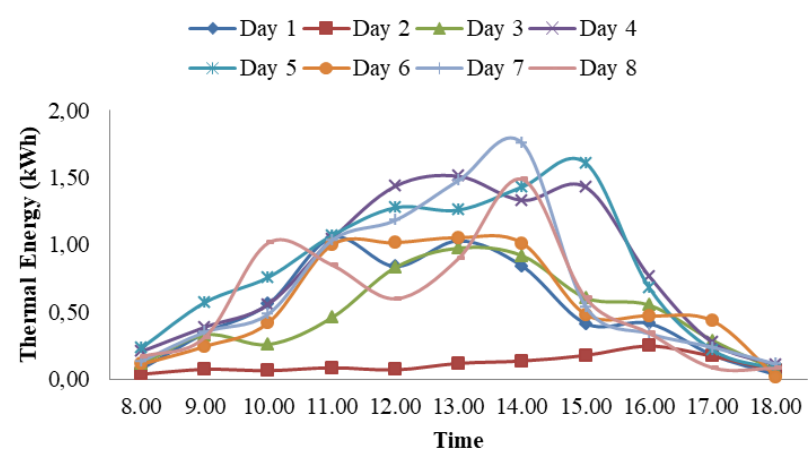

Fig. 3. Graph of the Thermal Energy.

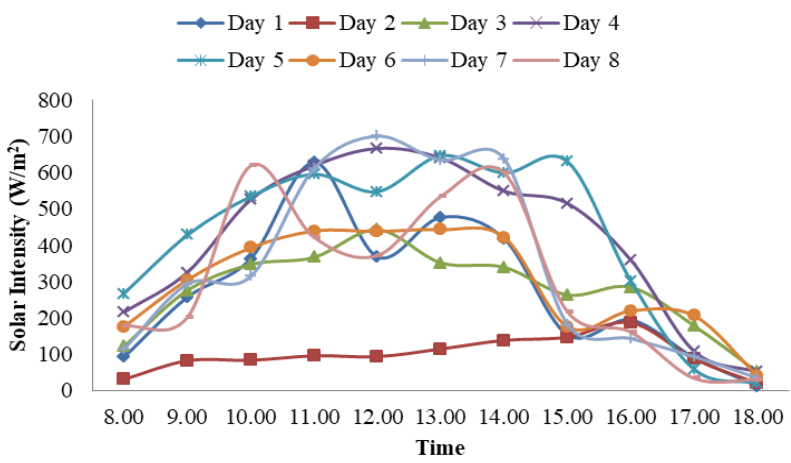

Fig. 4. Graph of the Solar Intensity .

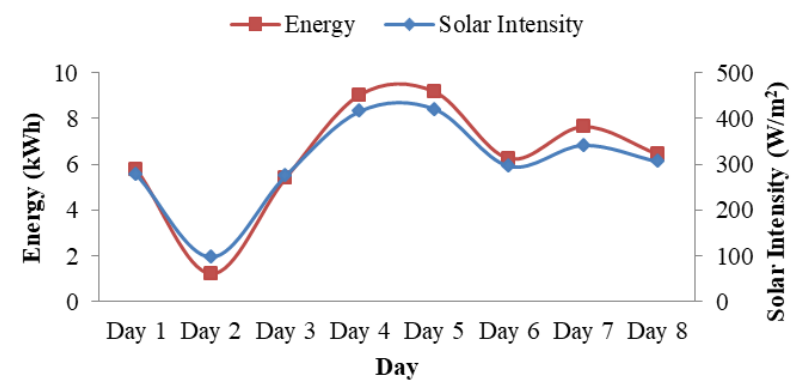

Fig. 5. Graph of the Solar Intensity against Energy. 




Fig. 6. Graph of Ambient Temperature against Energy.

\section{DISCUSSION}

Figure 5 shows a graph of the relationship between the intensity of the sun and the amount of energy produced in a double slope passive solar water distiller system. From the figure, it can be seen that the increase or decrease in thermal energy is proportional to the solar intensity. The fifth day is the day where the greatest solar intensity is obtained so that the thermal energy produced on the fifth day is the highest energy compared to other days.

Figure 6 shows a graph of the relationship between environmental temperature and the amount of energy produced in a passive solar water distiller system with a double slope. Based on the research that has been done, it can be seen in the figure that the highest environmental temperature is on the fifth day, this shows that the environmental temperature tends to follow the magnitude of the sun's intensity. On the fifth day, the energy produced was $9.18 \mathrm{kWh}$ and the lowest was 1.23 $\mathrm{kWh}$ which occurred on the second day of the study.

Thermal energy depends on the heat transfer coefficient and the amount of water produced. If the displacement coefficient is high, the thermal energy generated in the system will increase. The lower the temperature in the glass and the wider the basin is used, the greater the thermal energy. The low thermal energy on the second day is due to low sun intensity, so that the evaporation coefficient is lower. The results of this study indicate that the thermal energy produced is greater than the research that has been done by previous researchers. This can be caused by the intensity of the sun and the lower environmental temperature at the research site compared to previous studies.

\section{CONCLUSIONS}

Based on the results obtained in this study, it is known that the amount of thermal energy produced is on the fifth day with the energy of $9.18 \mathrm{kWh}$ and the lowest energy of 1.23 which is generated on the second day. Thermal energy is influenced by the heat transfer coefficient and the amount of water produced by the system. The heat transfer coefficient is influenced by the intensity of the sun and environmental temperature, this also occurs in the large amount of water produced. The greater the heat transfer coefficient and the amount of water produced, the greater the thermal energy produced by the system.

\section{REFERENCES}

[1] J.H.T. Saragi, F.H. Napitupulu, A.H. Nasution, and H. Ambarita, "Exergy analysis of double slope passive solar still," IOP Conf. Ser. Mater. Sci. Eng., vol. 725, no. 1, 2020.

[2] P. Durkaieswaran and K.K. Murugavel, "Various special designs of single basin passive solar still - A review," Renew. Sustain. Energy Rev., vol. 49, pp. 1048-1060, 2015.

[3] J.F.H. Saragi and W.S. Damanik, "Energy and Exergy Efficiency of Double Slope Passive Solar Still,” J. Mech. Eng. Sci. Technol., vol. 4, no. 2, pp. 82-90, 2020.

[4] M.A. Eltawil, Z. Zhengming, and L. Yuan, "A review of renewable energy technologies integrated with desalination systems," Renew. Sustain. Energy Rev., vol. 13, no. 9, pp. 2245-2262, 2009.

[5] H. Zheng, Solar energy desalination technology. 2017.

[6] L. Sahota and G. N. Tiwari, "Exergoeconomic and enviroeconomic analyses of hybrid double slope solar still loaded with nanofluids," Energy Convers. Manag., vol. 148, pp. 413-430, 2017.

[7] W.S. Damanik, F.H. Napitupulu, A.H. Nasution, and H. Ambarita, "Energy analysis of double slope aktive solar still," IOP Conf. Ser. Mater. Sci. Eng., vol. 725, no. 1, 2020.

[8] A.K. Tiwari and G.N. Tiwari, "Effect of water depths on heat and mass transfer in a passive solar still: in summer climatic condition," Desalination, vol. 195, no. 1-3, pp. 78-94, 2006.

[9] B. Viswanathan, Energy Sources: Fundamentals of Chemical Conversion Processes and Applications. 2016.

[10] L. Sahota, Shyam, and G.N. Tiwari, "Energy matrices, enviroeconomic and exergoeconomic analysis of passive double slope solar still with water based nanofluids," Desalination, vol. 409, pp. 66-79, 2017.

[11] V.K. Dwivedi and G.N. Tiwari, "Annual Energy and Exergy Analysis of Single and Double Slope Passive Solar Stills," Trends in Applied Sciences Research, vol. 3. pp. 225-241, 2008.

[12] G.N. Tiwari and L. Sahota, "Review on the energy and economic efficiencies of passive and active solar distillation systems," Desalination, vol. 401, pp. 151-179, 2017.

[13] L. Sahota and G.N. Tiwari, "Effect of Al2O3 nanoparticles on the performance of passive double slope solar still," Sol. Energy, vol. 130, pp. 260-272, 2016.

[14] V.K. Dwivedi and G.N. Tiwari, "Comparison of internal heat transfer coefficients in passive solar stills by different thermal models: An experimental validation," Desalination, vol. 246, no. $1-3$, pp. 304-318, 2009.

[15] D.B. Singh, G.N. Tiwari, I.M. Al-Helal, V.K. Dwivedi, and J.K. Yadav, "Effect of energy matrices on life cycle cost analysis of passive solar stills," Sol. Energy, vol. 134, pp. 9-22, 2016.

[16] R.V. Singh, R. Dev, M.M. Hasan, and G.N. Tiwari, "Comparative Energy and Exergy Analysis of Various Passive Solar Distillation Systems," Proc. World Renew. Energy Congr. - Sweden, 8-13 May, 2011, Linköping, Sweden, vol. 57, pp. 3929-3936, 2011. 